\title{
IMPLEMENTASI APLIKASI SISTEM PENYUSUNAN JADWAL KULIAH PADA JURUSAN TEKNIK ELEKTRO UIN SULTAN SYARIF KASIM
}

\author{
Oktaf Brillian Kharisma ${ }^{\mathrm{a}, 1,{ }^{*}, \text { Reski Riandi }}{ }^{\mathrm{b}, 2}$ \\ ${ }^{a}$ Fakultas Sains dan Teknologi, UIN Sultan Syarif Kasim Pekanbaru \\ ${ }^{\mathrm{b}}$ Fakultas Sains dan Teknologi, UIN Sultan Syarif Kasim Pekanbaru \\ ${ }^{1}$ brilliankhar@gmail.com *; ${ }^{2}$-reskiriandi@gmail.com \\ * corresponding author
}

\section{ARTICLE INFO}

\section{Keywords}

Penjadwalan kuliah

Aplikasi

PHP

MySQL

\section{ABSTRACT}

Proses penyusunan jadwal perkuliahan merupakan kegiatan rutin setiap universitas dalam menghadapi setiap semester baru. Jurusan Teknik Elektro UIN Suska Riau, penyusunan jadwal perkuliahan masih menggunakan program Microsoft Excel. Sehingga, pembuatan jadwal tersebut masih kurang efisien karena prosesnya membutuhkan waktu yang lama dan harus melakukan revisi jadwal yang bentrok. Maka,dibutuhkan sebuah sistem yang dapat menangani proses penjadwalan perkuliahan tersebut dengan menerapkan metode asosiasi berbasis web. Denagan adanya aplikasi ini nantinya proses perkuliahan di jurusan teknik elektro dapat dapat dilakukan tanpa adanya jadwal perkuliahan yang bentrok dan proses penyusunannya dapat dilakukan dengan cepat. Aplikasi yang dibangun akan mengenerate otomatis dan menampilkan jadwal berupa tabel penjadwalan secara keseluruhan yaitu berupa data dosen, data waktu, data mata kuliah, dan data ruangan. Dari hasil uji beta yang dilakukan oleh 100 dosen sebagai subjek penguji menyatakan bahwa keberhasilan system sebesar $75 \%$.

\section{Pendahuluan}

Penyusunan jadwal kuliah merupakan kegiatan rutin dalam sistem akademik di Universitas atau Perguruan Tinggi yang dilakukan dalam menghadapi setiap semester baru. Penyusunan jadwal juga sesuatu hal yang penting dalam mengatur proses perkuliahan agar tidak terjadinya bentrok antara satu mata kuliah dengan mata kuliah yang lain.

Permasalahan yang dihadapi dalam penyusunan jadwal kuliah khususnya dijurusan Teknik Elektro UIN Suska Riau masih menggunakan cara manual dengan mencocokkan satu persatu mata kuliah dengan lokal, jam, ruangan, dan dosen yang ada, meski menggunakan logika/formula yang ada pada Microsoft Excel tetapi ini masih kurang efektif dan masih ada mata kuliah yang bentrok antara satu dengan yang lainnya. Hal ini mengakibatkan perkuliahan di awal semester kurang efektif karena harus melakukan revisi jadwal berulang kali sampai sesuai dengan kebutuhan Akademik.

Penjadwalan juga perlu adanya optimasi. Oleh karena itu, pembuatan sistem penjadwalan kuliah ini dilakukan dengan berbagai perbaikan untuk menghindari terjadinya bentrok pada penjadwal. Pembuatan aplikasi ini menggunakan bahasa pemrograman Hypertext PreProcessor (PHP) untuk membangun sistem, dan MySQL sebagai database untuk menyimpan data yang diperlukan dalam pembuatan aplikasi ini. 
Aplikasi penyusunan jadwal Kuliah ini akan sangat membantu bagi Universitas dalam pembuatan jadwal kuliah. Juga akan sangat efektif yaitu tidak akan terdapat mata kuliah yang bentrok karena aplikasi ini sudah dibuat untuk mengatasi hal tersebut.

\section{Metode Penelitian}

Metode penelitian diawali dengan observasi terhadap sistem penyusunan jadwal perkuliahan yang ada di jurusan teknik elektro UIN Sultan syarif kasim. Hal ini dilakukan untuk untuk mengumpulkan informasi untuk kebutuhan pembuatan sistem. Sistem di buat berdasarkan informasi yang diperoleh, antara lain data ruang, data mata kuliah, data dosen, data kelas, hari dan jam sebagai input untuk pembuatan jadwal. Sedangkan ouput yang diperolah adalah berupa tabel penjadwalan kuliah. Kemudian, tahapan selanjutnya adalah desain sistem. Sistem ini dirancang menggunakan metode scramble yang berarti bahwa setiap dosen akan dapat menentukan jadwalnya masing-masing secara acak sebelum nantinyadi generate untuk menentukan waktu dan jadwal perkuliahan.

\subsection{Perancangan Database}

Hal mendasar yang harus dipenuhi dalam pembuatan sistem ini adalah Perancangan database yang menggunakan ERD (Entity Relationship Diagram).

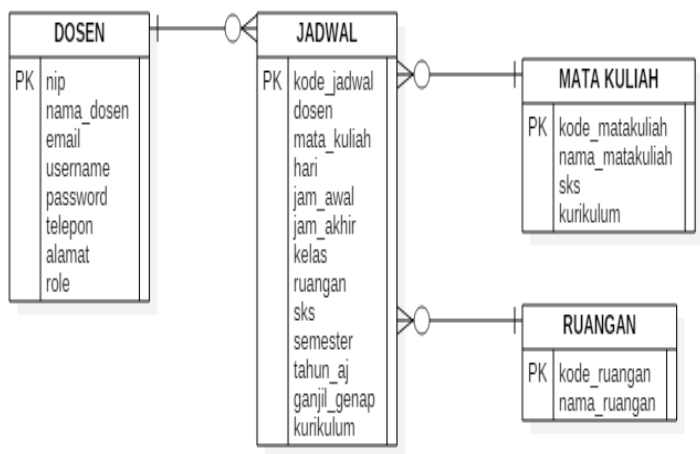

Gambar 1. ERD (Entity Relationship Diagram)

\subsection{Perancangan Aplikasi}

Proses perancangan digambarkan menggunakan usecase diagram. Sebagaimana berikut: 


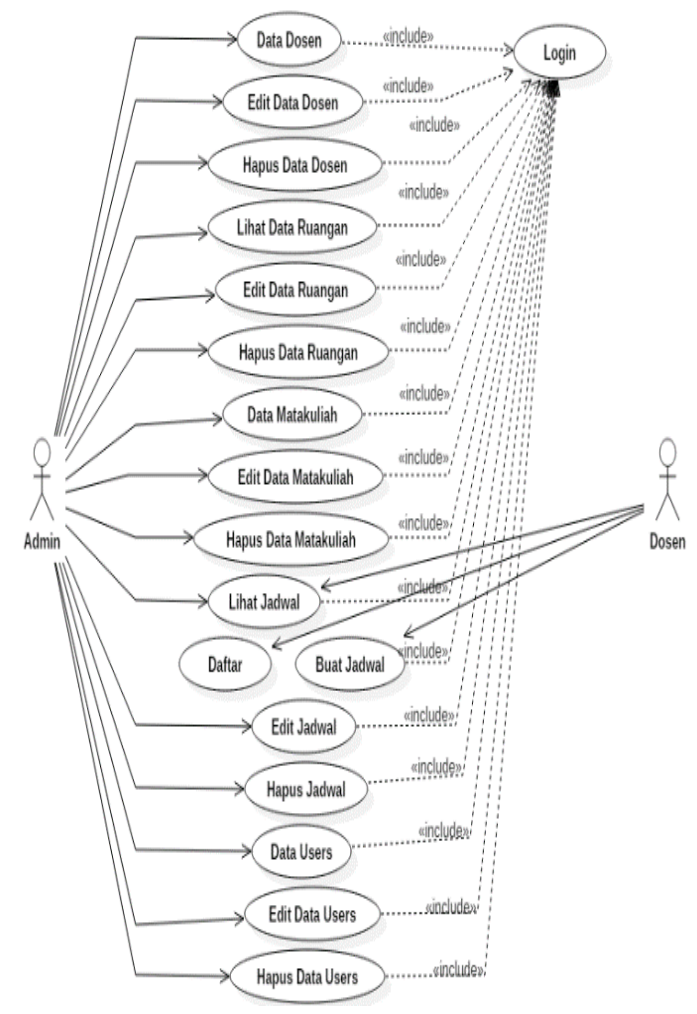

Gambar 2. Usecase diagram

\section{Hasil Dan Pembahasan}

\subsection{Implementasi Sistem}

Hasil implementasi setiap halaman aplikasi adalah sebagaimana berikut ini :

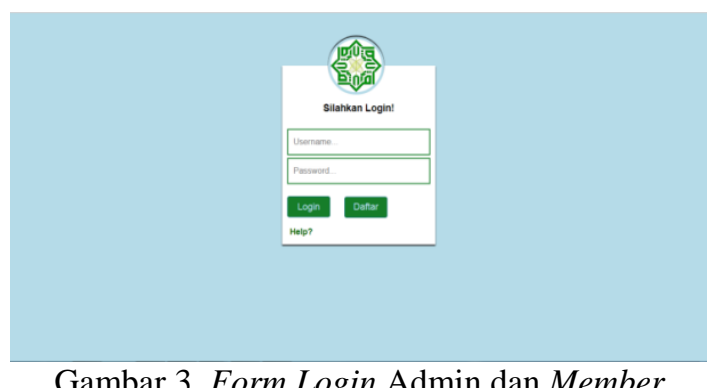

Gambar 3. Form Login Admin dan Member 


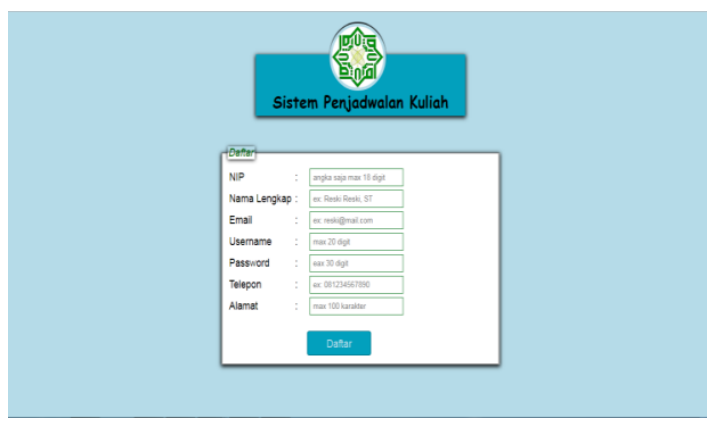

Gambar 4. Form Daftar Member

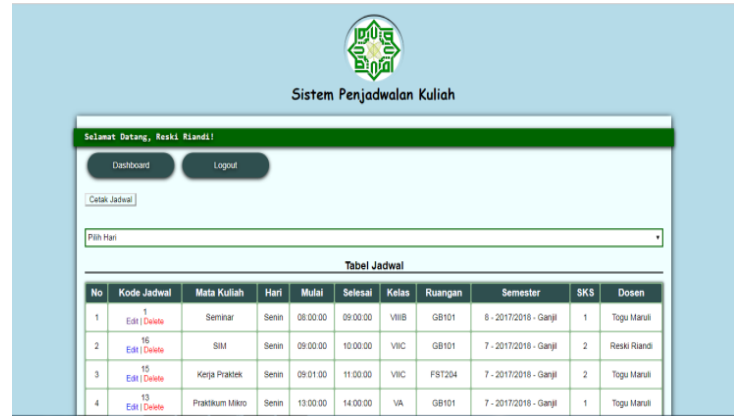

Gambar 5. Tampilan Halaman Utama

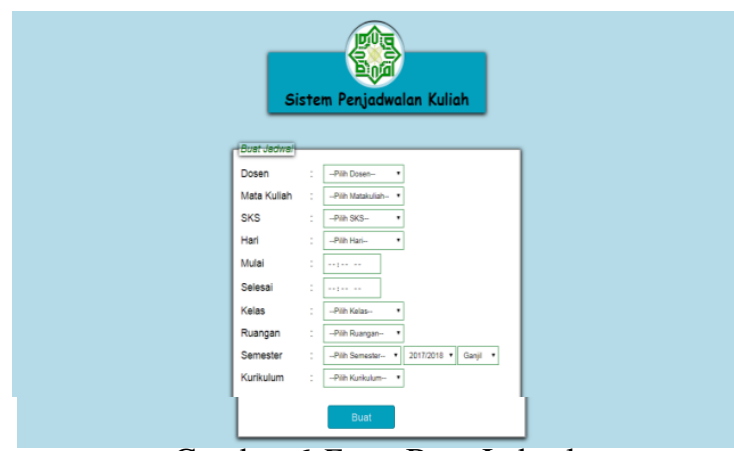

Gambar 6 Form Buat Jadwal

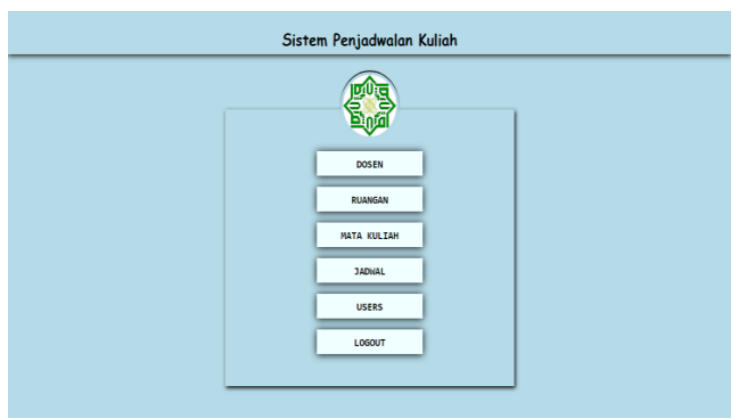

Gambar 7. Tampilan Halaman Dashboard 


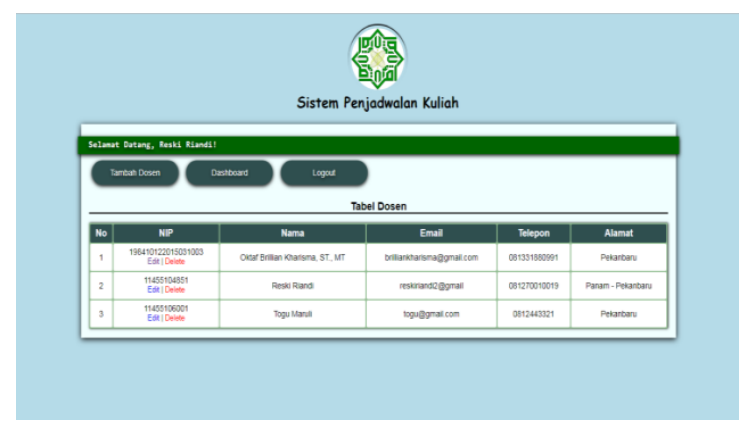

Gambar 8. Tampilan Data Dosen

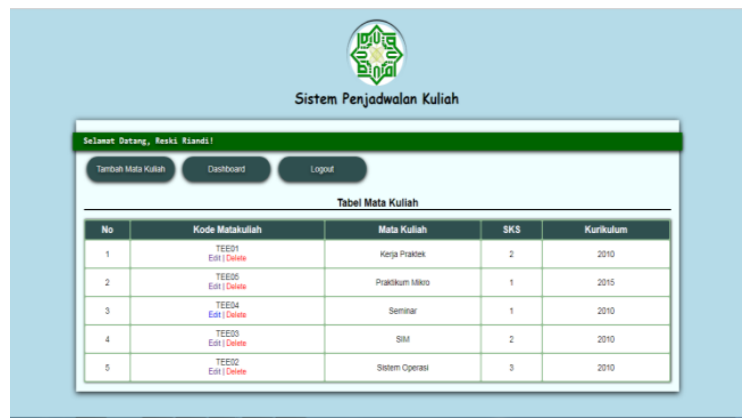

Gambar 9. Tampilan Data Mata Kuliah

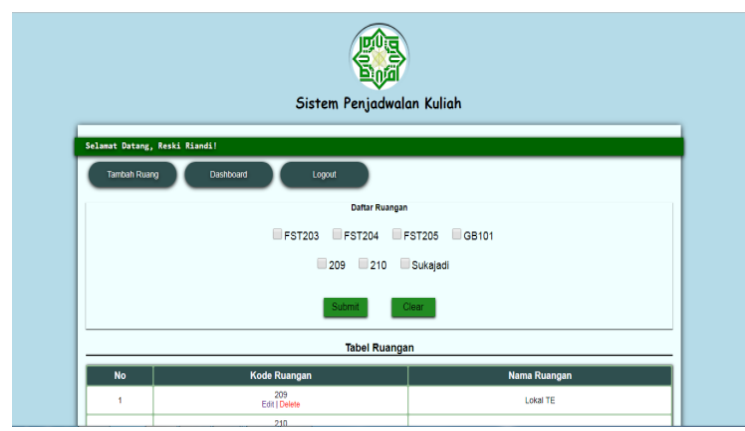

Gambar 10. Tampilan Data Ruangan

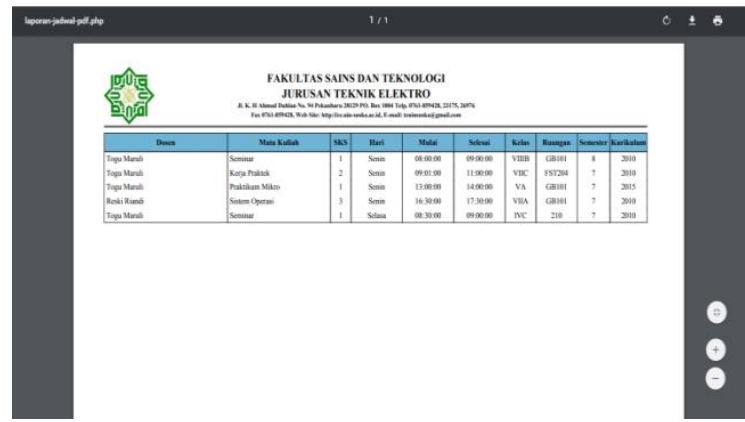

Gambar 11. Tampilan Report Jadwal

\subsection{Pengujian Aplikasi}

a. Pengujian Black Box 
Black box testing merupakan teknik pengujian yang berfokus pada keluaran hasil dari respon masukan, atau secara sederhana black box merupakan proses menjalankan aplikasi untuk mengetahui apakah ada error atau ada fungsi yang tidak berjalan sesuai harapan.Berikut hasil pengujian menggunakan metode black box:

Tabel 1. Pengujian Login Admin dan Dosen

\begin{tabular}{|c|c|c|c|c|}
\hline \multicolumn{5}{|c|}{ Kasus } \\
\hline \multicolumn{5}{|c|}{ Login Admin } \\
\hline $\begin{array}{c}\text { Skenario } \\
\text { Uji }\end{array}$ & \multicolumn{2}{|c|}{$\begin{array}{c}\text { Hasil yang } \\
\text { Diharapkan }\end{array}$} & Pengamatan & Hasil Uji \\
\hline $\begin{array}{l}\text { Masukkan } \\
\text { Username } \\
\text { dan } \\
\text { Password } \\
\text { Admin } \\
\text { yang benar. }\end{array}$ & \multicolumn{3}{|c|}{$\begin{array}{l}\text { Ketika data login } \\
\text { dimasukkan dan } \\
\text { tombol Login diklik } \\
\text { maka akan dilakukan } \\
\text { proses pengecekan } \\
\text { data login. Jika data } \\
\text { login benar maka } \\
\text { akan masuk ke } \\
\text { halaman dashboard. }\end{array}$} & $\begin{array}{c}\text { Diterima } \\
{[\mathrm{X}]} \\
\text { Ditolak } \\
{[\quad]}\end{array}$ \\
\hline \multicolumn{5}{|c|}{ Kasus } \\
\hline \multicolumn{5}{|c|}{ LoginMember/Dosen } \\
\hline $\begin{array}{l}\text { Masukkan } \\
\text { Username } \\
\text { dan } \\
\text { Password } \\
\text { Dosen } \\
\text { yang } \\
\text { benar. }\end{array}$ & $\begin{array}{l}\text { Ketika data } \\
\text { login } \\
\text { dimasukkan } \\
\text { dan tombol } \\
\text { Login diklik } \\
\text { maka akan } \\
\text { dilakukan } \\
\text { proses } \\
\text { pengecekan } \\
\text { data login. } \\
\text { Jika data } \\
\text { login benar } \\
\text { maka akan } \\
\text { masuk ke } \\
\text { halaman } \\
\text { utama. }\end{array}$ & $\begin{array}{l}\text { Masu } \\
\text { utame }\end{array}$ & ke halaman & $\begin{array}{c}\text { Diterima } \\
\quad[\mathrm{X}] \\
\text { Ditolak } \\
{[\quad]}\end{array}$ \\
\hline \multicolumn{5}{|c|}{ Kasus } \\
\hline \multicolumn{5}{|c|}{ Kesalahan data login } \\
\hline $\begin{array}{l}\text { Masukkan } \\
\text { Username } \\
\text { dan } \\
\text { Password } \\
\text { Admin } \\
\text { dan Dosen } \\
\text { yang } \\
\text { salah. }\end{array}$ & $\begin{array}{l}\text { Tidak bisa } \\
\text { login dan } \\
\text { menampilkan } \\
\text { pesan. }\end{array}$ & $\begin{array}{l}\text { Tamp } \\
\text { "User } \\
\text { Passv } \\
\text { terdat }\end{array}$ & $\begin{array}{l}\text { pesan } \\
\text { ime atau } \\
\text { rd belum } \\
\text { !!" }\end{array}$ & $\begin{array}{c}\text { Diterima } \\
\text { [X] } \\
\text { Ditolak } \\
{[\quad]}\end{array}$ \\
\hline
\end{tabular}

Tabel 2. Pengujian Form Daftar

\begin{tabular}{|c|c|c|c|}
\hline \multicolumn{4}{|c|}{ Kasus } \\
\hline \multicolumn{4}{|c|}{ Tombol Simpan } \\
\hline Skenario Uji & Hasil yang Diharapkan & Pengamatan & Hasil Uji \\
\hline $\begin{array}{l}\text { Masukkan data } \\
\text { member/dosen pengampu } \\
\text { yang ingin membuat } \\
\text { jadwal. }\end{array}$ & $\begin{array}{l}\text { Ketika data dosen dimasukkan dan } \\
\text { tombol Daftar diklik, maka akan } \\
\text { langsung masuk ke halaman login. }\end{array}$ & $\begin{array}{l}\text { Masuk ke halaman login } \\
\text { dan keluar pesan } \\
\text { "Selamat anda sudah } \\
\text { terdaftar, silahkan login". }\end{array}$ & $\begin{array}{c}\text { Diterima } \\
{[\mathrm{X}]} \\
\text { Ditolak } \\
{[\mathrm{]}}\end{array}$ \\
\hline & Kasus & & \\
\hline
\end{tabular}




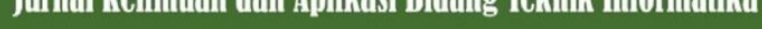

\begin{tabular}{llll}
\hline & \multicolumn{2}{c}{ Validasi data sama } & \\
\hline & $\begin{array}{l}\text { Tidak bisa mendaftar dan } \\
\text { menampilkan pesan. }\end{array}$ & $\begin{array}{l}\text { Tampil pesan "Username } \\
\text { atau email sudah }\end{array}$ & $\begin{array}{c}\text { Diterima } \\
\text { terdaftar!” }\end{array}$ \\
$\begin{array}{l}\text { member/dosen pengampu } \\
\text { yang ingin membuat }\end{array}$ & & \\
$\begin{array}{l}\text { jadwal tetapi } \text { username } \\
\text { dan email sama dengan }\end{array}$ & & Ditolak \\
tersimpan di database. & {$[$ ] } \\
\hline
\end{tabular}

Tabel 3. Pengujian Form Data Dosen

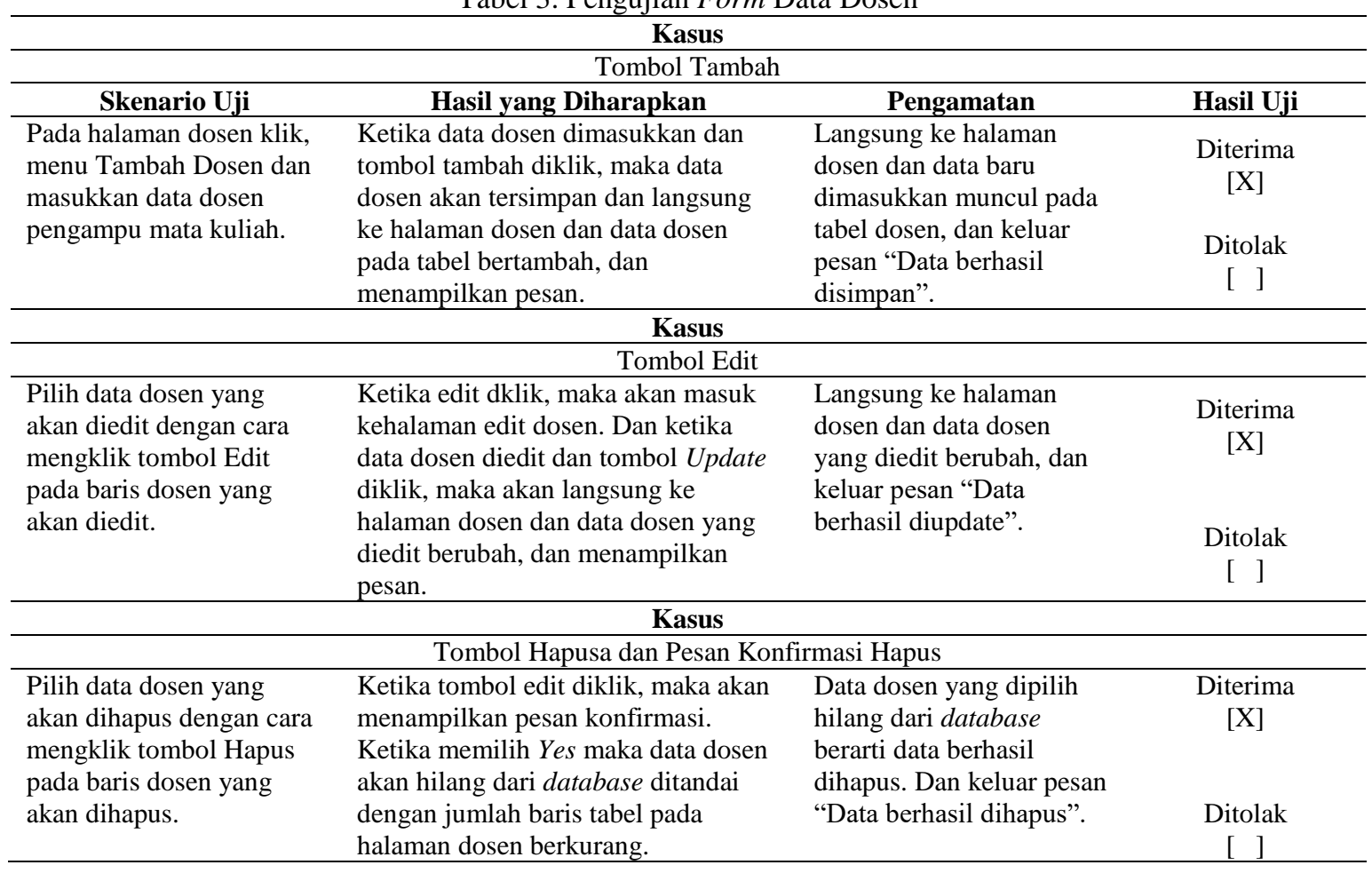

Tabel 4. Pengujian Form Data Mata Kuliah

\begin{tabular}{|c|c|c|c|}
\hline \multicolumn{4}{|c|}{ Kasus } \\
\hline \multicolumn{4}{|c|}{ Tombol Tambah } \\
\hline Skenario Uji & Hasil yang Diharapkan & Pengamatan & Hasil Uji \\
\hline $\begin{array}{l}\text { Pada halaman mata kuiah, } \\
\text { klik menu Tambah Mata } \\
\text { Kuliah dan masukkan data } \\
\text { dosen mata kuliah. }\end{array}$ & $\begin{array}{l}\text { Ketika data mata kuliah dimasukkan } \\
\text { dan tombol tambah diklik, maka data } \\
\text { mata kuliah akan tersimpan dan } \\
\text { langsung ke halaman Mata Kuliah } \\
\text { dan data mata kuliah pada tabel } \\
\text { bertambah, dan menampilkan pesan. }\end{array}$ & $\begin{array}{l}\text { Langsung ke halaman } \\
\text { Mata Kuliah dan data } \\
\text { baru dimasukkan muncul } \\
\text { pada tabel mata kuliah, } \\
\text { dan keluar pesan "Data } \\
\text { berhasil disimpan". }\end{array}$ & $\begin{array}{l}\text { Diterima } \\
\quad[\mathrm{X}] \\
\text { Ditolak } \\
\quad[\quad]\end{array}$ \\
\hline \multicolumn{4}{|c|}{ Kasus } \\
\hline \multicolumn{4}{|c|}{ Tombol Edit } \\
\hline $\begin{array}{l}\text { Pilih data mata kuliah } \\
\text { yang akan diedit dengan } \\
\text { cara mengklik tombol Edit } \\
\text { pada baris mata kuliah } \\
\text { yang akan diedit. }\end{array}$ & $\begin{array}{l}\text { Ketika edit dklik, maka akan masuk } \\
\text { kehalaman edit mata kuliah. Dan } \\
\text { ketika data mata kuliah diedit dan } \\
\text { tombol Update diklik, maka akan } \\
\text { langsung ke halaman mata kuliah dan } \\
\text { data mata kuliah yang diedit berubah, } \\
\text { dan menampilkan pesan. }\end{array}$ & $\begin{array}{l}\text { Langsung ke halaman } \\
\text { mata kuliah dan data mata } \\
\text { kuliah yang diedit } \\
\text { berubah, dan keluar pesan } \\
\text { "Data berhasil diupdate". }\end{array}$ & $\begin{array}{c}\text { Diterima } \\
{[\mathrm{X}]}\end{array}$ \\
\hline & $\begin{array}{ll} & \text { Kasus } \\
\end{array}$ & & \\
\hline
\end{tabular}


Pilih data mata kuliah yang akan dihapus dengan cara mengklik tombol Hapus pada baris mata kuliah yang akan dihapus.
Tombol Hapus dan Pesan Konfirmasi Hapus

Ketika tombol edit diklik, maka akan Data mata kuliah yang menampilkan pesan konfirmasi. Ketika memilih Yes maka data mata kuliah akan hilang dari database.
Diterima

database berarti data

berhasil dihapus. Dan

keluar pesan "Data

berhasil dihapus".
Ditolak

Tabel 5. Pengujian Form Data Ruangan

\begin{tabular}{|c|c|c|c|}
\hline \multicolumn{4}{|c|}{ Kasus } \\
\hline \multicolumn{4}{|c|}{ Tombol Tambah } \\
\hline Skenario Uji & Hasil yang Diharapkan & Pengamatan & Hasil Uji \\
\hline $\begin{array}{l}\text { Pada halaman Ruangan, } \\
\text { klik menu Tambah } \\
\text { Ruangan dan masukkan } \\
\text { data dosen mata kuliah. }\end{array}$ & $\begin{array}{l}\text { Ketika data ruangan dimasukkan dan } \\
\text { tombol tambah diklik, maka data } \\
\text { mata kuliah akan tersimpan dan } \\
\text { langsung ke halaman Ruangan dan } \\
\text { data ruangan pada tabel bertambah, } \\
\text { dan menampilkan pesan. }\end{array}$ & $\begin{array}{l}\text { Langsung ke halaman } \\
\text { Ruangan dan data baru } \\
\text { dimasukkan muncul pada } \\
\text { tabel ruangan, dan keluar } \\
\text { pesan "Data berhasil } \\
\text { disimpan". }\end{array}$ & $\begin{array}{l}\text { Diterima } \\
\qquad[\mathrm{X}] \\
\text { Ditolak } \\
\quad[\quad]\end{array}$ \\
\hline \multicolumn{4}{|c|}{ Kasus } \\
\hline \multicolumn{4}{|c|}{ Tombol Edit } \\
\hline $\begin{array}{l}\text { Pilih data ruangan yang } \\
\text { akan diedit dengan cara } \\
\text { mengklik tombol Edit } \\
\text { pada baris ruangan yang } \\
\text { akan diedit. }\end{array}$ & $\begin{array}{l}\text { Ketika edit dklik, maka akan masuk } \\
\text { kehalaman edit ruangan. Dan ketika } \\
\text { data ruangan diedit dan tombol } \\
\text { Update diklik, maka akan langsung } \\
\text { ke halaman Ruangan dan data } \\
\text { ruangan yang diedit berubah, dan } \\
\text { menampilkan pesan. }\end{array}$ & $\begin{array}{l}\text { Langsung ke halaman } \\
\text { Ruangan dan data } \\
\text { ruangan yang diedit } \\
\text { berubah, dan keluar pesan } \\
\text { "Data berhasil diupdate". }\end{array}$ & $\begin{array}{c}\text { Diterima } \\
{[\mathrm{X}]}\end{array}$ \\
\hline \multicolumn{4}{|c|}{ Kasus } \\
\hline \multicolumn{4}{|c|}{ Tombol Hapus dan Pesan Konfirmasi Hapus } \\
\hline \multirow[t]{2}{*}{$\begin{array}{l}\text { Pilih data ruangan yang } \\
\text { akan dihapus dengan cara } \\
\text { mengklik tombol Hapus } \\
\text { pada baris ruangan yang } \\
\text { akan dihapus. }\end{array}$} & $\begin{array}{l}\text { Ketika tombol edit diklik, maka akan } \\
\text { menampilkan pesan konfirmasi. } \\
\text { Ketika memilih Yes maka data } \\
\text { ruangan akan hilang dari database } \\
\text { ditandai dengan jumlah baris tabel } \\
\text { pada halaman ruangan berkurang. }\end{array}$ & $\begin{array}{l}\text { Data ruangan yang dipilih } \\
\text { hilang dari database } \\
\text { berarti data berhasil } \\
\text { dihapus. Dan keluar pesan } \\
\text { "Data berhasil dihapus". }\end{array}$ & $\begin{array}{c}\text { Diterima } \\
{[\mathrm{X}]}\end{array}$ \\
\hline & & & $\begin{array}{c}\text { Ditolak } \\
\text { [ ] }\end{array}$ \\
\hline
\end{tabular}

Tabel 6. Pengujian Proses Penjadwalan

\begin{tabular}{|c|c|c|c|}
\hline \multicolumn{4}{|c|}{ Kasus } \\
\hline \multicolumn{4}{|c|}{ Tombol Buat Jadwal } \\
\hline Skenario Uji & Hasil yang Diharapkan & Pengamatan & Hasil Uji \\
\hline $\begin{array}{l}\text { Klik menu Buat Jadwal, } \\
\text { masukkan jadwal dengan } \\
\text { cara memasukkan data } \\
\text { penjadwalan pada form } \\
\text { buat jadwal. }\end{array}$ & $\begin{array}{l}\text { Ketika data jadwal dimasukkan dan } \\
\text { tombol Buat diklik, maka jadwal } \\
\text { akan tersimpan di database ditandai } \\
\text { dengan munculnya data pada tabel } \\
\text { jadwal, dan keluar pesan. }\end{array}$ & $\begin{array}{l}\text { Data yang barus saja } \\
\text { dimasukkan muncul pada } \\
\text { tabel jadwal, dan keluar } \\
\text { pesan "Jadwal berhasil } \\
\text { dibuat". }\end{array}$ & $\begin{array}{l}\text { Diterima } \\
\quad[\mathrm{X}] \\
\text { Ditolak } \\
{[}\end{array}$ \\
\hline \multicolumn{4}{|c|}{ Kasus } \\
\hline \multicolumn{4}{|c|}{ Tombol Hapus dan Pesan Konfirmasi Hapus } \\
\hline $\begin{array}{l}\text { Pilih data jadwal yang } \\
\text { akan dihapus dengan cara } \\
\text { mengklik tombol Hapus } \\
\text { pada baris jadwal yang } \\
\text { akan dihapus. }\end{array}$ & $\begin{array}{l}\text { Ketika tombol Hapus diklik maka } \\
\text { akan muncul pesan konfirmasi. } \\
\text { Ketika memilih Yes maka data jadwal } \\
\text { akan hilang dari database. }\end{array}$ & $\begin{array}{l}\text { Data jadwal yang dipilih } \\
\text { hilang dari database } \\
\text { berarti data berhasil } \\
\text { dihapus. Dan keluar pesan } \\
\text { "Data berhasil dihapus". }\end{array}$ & $\begin{array}{l}\text { Diterima } \\
\quad[\mathrm{X}] \\
\text { Ditolak } \\
\text { [ ] ] }\end{array}$ \\
\hline \multicolumn{4}{|c|}{ Kasus } \\
\hline & Validasi Data Ganda/B & trok & \\
\hline
\end{tabular}


Masukkan data jadwal yang sama dengan jadwal yang sudah ada tersimpan pada database.
Ketika tombol Buat diklik maka jadwal tidak tersimpan dan muncul pesan jadwal bentrok.
Sesuai dengan

diharapkan, data jadwal

tidak tersimpan dan

keluar pesan.
Diterima

[X]

Ditolak

Tabel 7. Pengujian Report Penjadwalan

\begin{tabular}{lllc}
\hline \multicolumn{4}{c}{ Kasus } \\
\hline \multicolumn{1}{c}{ Cetak Jadwal } & \multicolumn{1}{c}{ Pengamatan } & Hasil Uji \\
\hline $\begin{array}{l}\text { Pada halaman utama, klik } \\
\text { tombol Cetak Jadwal. }\end{array}$ & $\begin{array}{l}\text { Ketika tombol Cetak Jadwal diklik, } \\
\text { maka akan tampil report penjadwalan } \\
\text { kseluruhan dan diurutkan berdasarkan } \\
\text { hari dan jam terkecil dalam bentuk } \\
\text { fpdf. }\end{array}$ & $\begin{array}{l}\text { Jadwal yang ditampilkan } \\
\text { sesuai dengan yang } \\
\text { diharapkan. }\end{array}$ & $\begin{array}{c}\text { Diterima } \\
{[\mathrm{X}]}\end{array}$ \\
& & & Ditolak \\
\end{tabular}

b. Analisis Beta

Pengujian beta merupakan pengujian untuk mendapatkan kesimpulan dari aplikasi yang telah dibuat, dengan cara memperoleh data dari kuesioner terhadap users atau pengguna secara langsung. Pengujian ini menggunakan kuisioner yang terdiri dari 9 pertanyaan yang ditanya kepada 20 responden, dengan menggunakan skala likert dengan skala 1 sampai 4.

Tabel 8. Skala Likert

\begin{tabular}{cl}
\hline No. & \multicolumn{1}{c}{ Keterangan } \\
\hline 1 & Tidak Baik \\
\hline 2 & Kurang Baik \\
\hline 3 & Baik \\
\hline 4 & Sangat Baik \\
\hline
\end{tabular}

Berdasarkan kuisioner maka dicari persentase jawaban dengan rumus kuisioner sebagai berikut:

$$
\text { c. } \mathrm{Y}=\frac{\mathrm{P}}{\mathrm{Q}} \times 100 \%
$$

Keterangan:

$$
\begin{aligned}
\mathrm{Y}= & \text { Nilai persentase. } \\
\mathrm{P}= & \text { Banyaknya jawaban reponden dari } \\
& \text { tiap jawaban. } \\
\mathrm{Q}= & \text { Jumlah responden. }
\end{aligned}
$$

\begin{tabular}{|c|c|c|c|c|c|c|c|c|c|c|c|c|c|}
\hline \multirow{3}{*}{ No } & \multirow{3}{*}{$\begin{array}{l}\text { Item } \\
\text { Perta- } \\
\text { nyaan }\end{array}$} & \multicolumn{8}{|c|}{ Tanggapan Responden } & \multirow{3}{*}{$\mathbf{N}$} & \multirow{3}{*}{$\begin{array}{l}\text { Total } \\
\text { Skor }\end{array}$} & \multirow{3}{*}{$\%$} & \multirow{3}{*}{ Kategori } \\
\hline & & \multicolumn{2}{|c|}{ SB (4) } & \multicolumn{2}{|c|}{ B (3) } & \multicolumn{2}{|c|}{$\begin{array}{c}\text { KB } \\
(2) \\
\end{array}$} & \multicolumn{2}{|c|}{$\begin{array}{l}\text { TB } \\
(\mathbf{1}) \\
\end{array}$} & & & & \\
\hline & & f & $\%$ & f & $\%$ & f & $\%$ & f & $\%$ & & & & \\
\hline 1 & Item 1 & 8 & 40 & 10 & 50 & 2 & 10 & 0 & 0 & 20 & 66 & 82,50 & Sangat Baik \\
\hline 2 & Item 2 & 8 & 40 & 10 & 50 & 2 & 10 & 0 & 0 & 20 & 66 & 82,50 & Sangat Baik \\
\hline 3 & Item 3 & 8 & 40 & 9 & 45 & 3 & 15 & 0 & 0 & 20 & 65 & 81,25 & Sangat Baik \\
\hline 4 & Item 4 & 11 & 55 & 8 & 40 & 1 & 5 & 0 & 0 & 20 & 70 & 87,50 & Sangat Baik \\
\hline 5 & Item 5 & 12 & 60 & 6 & 30 & 2 & 10 & 0 & 0 & 20 & 70 & 87,50 & Sangat Baik \\
\hline 6 & Item 6 & 11 & 55 & 8 & 40 & 1 & 5 & 0 & 0 & 20 & 70 & 87,50 & Sangat Baik \\
\hline 7 & Item 7 & 9 & 45 & 10 & 50 & 1 & 5 & 0 & 0 & 20 & 68 & 85,00 & Sangat Baik \\
\hline 8 & Item 8 & 10 & 50 & 8 & 40 & 2 & 10 & 0 & 0 & 20 & 68 & 85,00 & Sangat Baik \\
\hline 9 & Item 9 & 8 & 40 & 9 & 45 & 3 & 15 & 0 & 0 & 20 & 65 & 81,25 & Sangat Baik \\
\hline
\end{tabular}

Setiap hasil persentase pertanyaan dari kuesioner dapat di lihat pada Tabel 9.

Tabel 9. Deskripsi Tanggapan Responden 


\begin{tabular}{cccc}
\hline Jumlah skor & 608 & & \\
\hline Rata-rata & 68 & 85,00 & $\begin{array}{c}\text { Sangat } \\
\text { Baik }\end{array}$ \\
\hline
\end{tabular}

Untuk menentukan kriteria atau kategori dari setiap pertanyaan, menggunakan rumus interval (I) sebagai berikut:

$$
I=\frac{100}{\text { Jumlah Skor (Likert) }}
$$

Berdasarkan rumus interval diatas, dimana jumlah skor $($ likert $)=4$ maka didapat $\mathrm{I}=\frac{100}{4}=25$. Jadi, jarak atau interval dari $0 \%$ sampai $100 \%$ adalah $25 \%$. Berikut kriteria interpretasi skornya berdasarkan interval:

Tabel 10. Persentase Kategori

\begin{tabular}{ccl}
\hline No. & \multicolumn{1}{c}{ Interval } & \multicolumn{1}{c}{ Kategori } \\
\hline 1 & $0 \%-24,99 \%$ & Tidak Baik \\
\hline 2 & $25 \%-49,99 \%$ & Kurang Baik \\
\hline 3 & $50 \%-74,99 \%$ & Baik \\
\hline 4 & $75 \%-100 \%$ & Sangat Baik \\
\hline
\end{tabular}

Agar mendapatkan hasil interpretasi, terlebih dahulu harus diketahui skor tertinggi (Y) dan skor terendah $(\mathrm{X})$ untuk item penilaian dengan rumus sebagai berikut:

$\mathrm{Y}=$ skor tertinggi likert $\times$ jumlah reponden $\mathrm{X}=$ terendah likert $\times$ jumlah reponden

Jumlah skor tertinggi untuk item "Sangat Baik" adalah 4 x $20=80$, sedangkan item "Tidak Baik" adalah 1 × $20=20$. Maka penilaian interpretasi responden dengan menggunkan rumus sebagi berikut, untuk menentukan kategori dari setiap pertanyaan:

$$
\text { Index } \%=\frac{\text { Total Skor }}{\mathrm{Y}} \times 100
$$

Berikut grafik persentase perbandingan item pertanyaan terhadap tanggapan responden: 


\section{JURNAL TEKNOLOGI INFORMASI}

[E-ISSN 2656-0321]

[Vol. 12 No. 2]

Jurnal Keilmutan dan Aplikasi Bidang Teknik Informatilka

[Agustus 2018]

J.r.

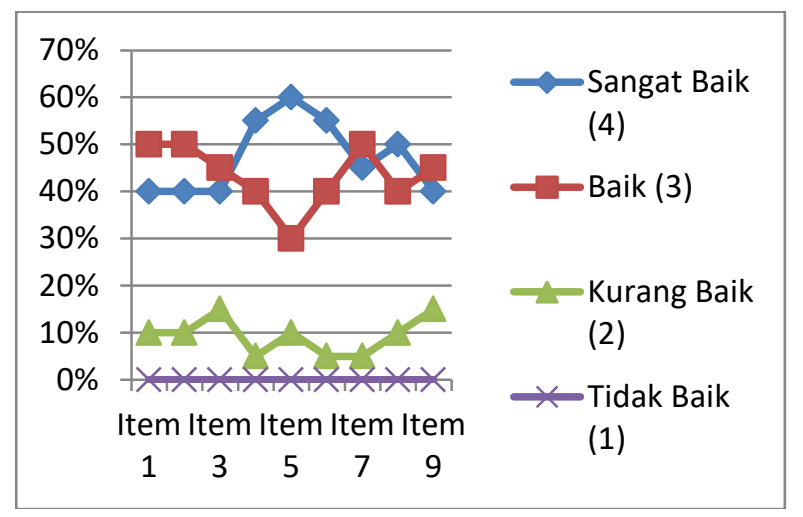

Gambar 12. Persentase Perbandingan Item Pertanyaan Terhadap Tanggapan Responden

Berikut persentase kategori dari setiap item pertanyaan yang diberikan kepada responden:

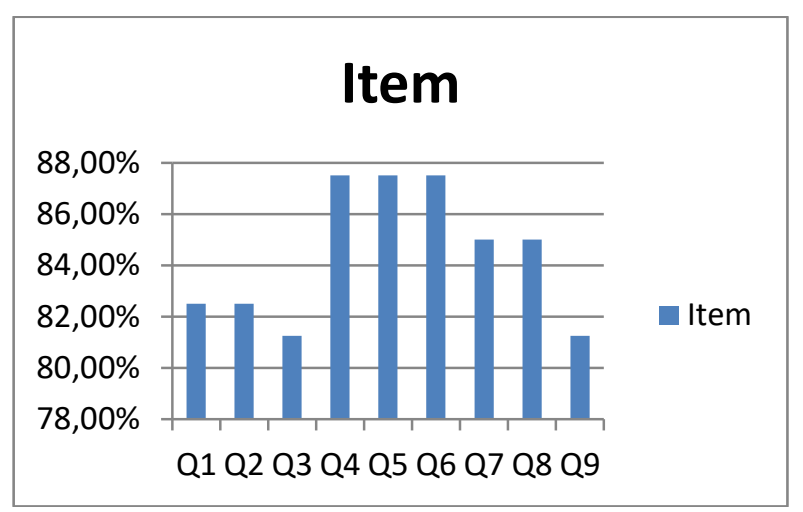

Grafik 13. Kategori per Item Pertanyaan

\section{Kesimpulan}

Dari hasil pembahasan dapat diambil beberapa kesimpulan, antara lain:

1. Telah dirancang dan dibuat aplikasi sistem penyusunan jadwal kuliah berbasis web dengan bahasa pemrograman PHP dan MySQL.

2. Proses penyusunan jadwal di-input oleh dosen yang mengampumata kuliah yang bersangkutan dengan cara mengisi data pada form penjadwalan.

3. Dengan pengimplementasian hasil dari rancangan kedalam sistem berbasis web didapatkan sistem yang dapat mempermudah proses penjadwalan dan pengolahan data seperti pemasukkan, penambahan dan pengecekan data. Serta dapat menghasilkan jadwal matakuliah yang anti bentrok.

4. Dengan adanya Aplikasi Penjadwalan Kuliah $W E B$ ini dapat mempermudah penyusunan jadwal perkuliahan.

\section{Daftar Pustaka}

[1] Hariyanto, B. 2004. Sistem Manajemen Basis Data. Bandung: Informatika

[2] Kustiyahningsih, Yeni \& Rosa Anamisa, Devie. 2011. Pemrograman Basis Data Berbasis Web Menggunakan PHP \& MySQL. Yogyakarka: Graha Ilmu. 
[3] Raharjo, Budi dkk. 2012. ModulPemrograman WEB (HTML, PHP, \& MySQL. Bandung: Modula.

[4] Saputra, A. 2011. Trik dan Solusi Jitu Pemograman PHP. Jakarta: Alex Media Komputindo.

[5] Wicaksono, Y. 2008. Membangun Bisnis Online dengan Mambo+. Alex Media. Jakarta: Komputindo. 